\title{
Mutational spectrum of NSDHL in CHILD syndrome
}

\author{
D Bornholdt, A König, R Happle, L Leveleki, M Bittar, R Danarti, A Vahlquist, W Tilgen, \\ U Reinhold, A Poiares Baptista, É Grosshans, P Vabres, S Niiyama, K Sasaoka, T Tanaka, \\ A L Meiss, P A Treadwell, D Lambert, F Camacho, K-H Grzeschik
}

C HILD syndrome (congenital hemidysplasia with ichthyosiform nevus and limb defects, MIM 308050) is an X linked dominant, male lethal, multisystem birth defect characterised by an inflammatory epidermal nevus showing a unique lateralisation pattern and strict midline demarcation. Hypoplasia or aplasia of skeletal or visceral structures may be found ipsilateral to the major cutaneous involvement. ${ }^{1}$ Owing to the highly characteristic clinical and histopathological features of the CHILD naevus, ${ }^{2}$ a diagnosis can be established not only in classical cases (fig 1) but also in cases with minimal or atypical involvement. ${ }^{3}$ In 2000, mutations in NSDHL (NAD(P)H steroid dehydrogenase-like protein) at Xq28 were identified by some of us to be the cause of this syndrome. ${ }^{4}$ Four additional NSDHL mutations have subsequently been reported in individuals with CHILD syndrome..$^{5-8}$ Studies carried out on the murine Nsdhl mutants bare patches (Bpa) and striated (Str) have shown that this gene

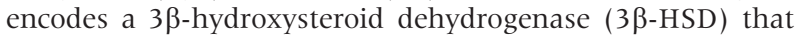
catalyses a step in the post-squalene cholesterol biosynthetic pathway and is localised within membranes of the endoplasmic reticulum and on the surface of intracellular lipid storage droplets. ${ }^{9-11}$ Non-functional NSDHL might cause the CHILD phenotype through a lack of cholesterol or other sterols downstream of the block in biosynthesis, or by the accumulation of intermediates upstream of the product generated by NSDHL.

A related trait, $\mathrm{X}$ linked dominant chondrodysplasia punctata (CDPX2, MIM 302960), ${ }^{22}$ is caused by mutations in $E B P$ (emopamil binding protein) at Xpl1.22-pl1.23 that functions similarly in the late cholesterol biosynthesis, downstream of NSDHL..$^{23}$ In the past, a case of X linked dominant chondrodysplasia punctata showing unilateral involvement was mistaken as an example of CHILD syndrome. ${ }^{25}$ Because abnormal sterol patterns suggestive of an $E B P$ mutation were found, the investigators erroneously concluded that CHILD syndrome is genetically heterogeneous. In fact, their case had all the clinical features of $X$ linked dominant chondrodysplasia punctata but none of the morphological criteria of CHILD syndrome. ${ }^{122}$ Hence there is so far no case report of CHILD syndrome showing a mutation outside the NSDHL locus.

In this study we describe mutations of the NSDHL gene that are likely to affect the function of the encoded protein in 14 unrelated female patients with CHILD syndrome, extending the spectrum of human NSDHL mutations by nine alleles not previously observed. Known mutations A105V, G205S, and $\mathrm{Y} 349 \mathrm{C}$ were found again in unrelated patients. Our molecular analysis confirms that CHILD syndrome is caused by loss of function of NSDHL and identifies highly conserved sites in the NSDHL protein, the mutation of which appears to be deleterious to this enzyme.

\section{METHODS}

Subjects

The study included 14 cases of CHILD syndrome (table 1). The diagnosis had been established before molecular analysis

\section{Key points}

- The gene $N A D(P) H$ steroid dehydrogenase-like (NSDHL) is mutated in CHILD syndrome (congenital hemidysplasia with ichthyosiform nevus and limb defects). Point mutations in the NSDHL gene have been detected in 14 unrelated female patients with CHILD syndrome. Brief clinical descriptions of the phenotypes and corresponding mutations are presented.

- As well as four stop mutations preventing the translation into full length protein, there were eight missense mutations, one mutation affecting a splice site, and one complete deletion of the gene. Two of the (unrelated) patients had an identical missense mutation, A105V.

- All NSDHL mutations known so far are discussed, including seven in the orthologous mouse gene Nsdhl. In four unrelated patients, A105 was mutated to V. In one mouse mutant the amino acid A94 of NSDHL, which takes a homologous position to A105 in the human enzyme, was mutated to T. Two patients showed G205S, and in three, Y349 was changed into $\mathrm{C}$ or $\mathrm{H}$.

- Nonsense and missense mutations spreading along the gene, as well as a complete deletion of the gene, result in similar phenotypes, suggesting that loss of function of the NSDHL protein causes this birth defect.

- Many of the amino acids altered in missense mutations are highly conserved during evolution. Most, however, are not directly located at positions considered to be essential in functional domains, such as the cofactor binding site or the active site at the catalytic centre. These mutations apparently affect other important sites within the NSDHL protein, the function of which awaits elucidation.

in all patients on clinical and histopathological criteria as described elsewhere. ${ }^{12426}$ Clinical features of 11 of these cases have been reported previously. Mutational analysis and examination of medical records were carried out with informed consent and under research protocols according to the Declaration of Helsinki. Table 1 shows whether CHILD syndrome occurred sporadically or whether other family members were affected. Of familial cases, only one affected individual was included in table 1 .

Abbreviations: CHILD, congenital hemidysplasia with ichthyosiform naevus and limb defects; MAPH, measurement by amplifiable probe hybridisation; NSDHL, NAD(P)H steroid dehydrogenase-like protein; SSCA, single strand conformation analysis 
Table 1 Synopsis of clinical data and molecular analysis in patients with CHILD syndrome

\begin{tabular}{|c|c|c|c|c|c|c|c|}
\hline & Family & $\begin{array}{l}\text { Clinical } \\
\text { description } \\
\text { (ref No) }\end{array}$ & Side & Ipsilateral CHILD naevus & Contralateral CHILD naevus & $\begin{array}{l}\text { Ipsilateral extracutaneous } \\
\text { defects }\end{array}$ & NSDHL mutation \\
\hline \multicolumn{8}{|c|}{ Newly observed NSDHL mutations in CHILD syndrome patients } \\
\hline 1 & - & 12 & R & $\begin{array}{l}\text { Diffuse involvement of trunk, } \\
\text { linear lesions on thigh }\end{array}$ & - & Hypoplasia of leg and foot & $\begin{array}{l}\text { c. } 108+2 T \rightarrow G \text {; splice } \\
\text { site }\end{array}$ \\
\hline 2 & - & 13 & $\mathrm{R}$ & $\begin{array}{l}\text { Widespread linear lesions } \\
\text { on trunk and leg, diffuse } \\
\text { involvement of groin }\end{array}$ & $\begin{array}{l}\text { Minor linear lesions } \\
\text { on hand }\end{array}$ & $\begin{array}{l}\text { Hypoplasia of pelvis and } \\
\text { femur; 6th finger at birth }\end{array}$ & c. $208 \mathrm{C} \rightarrow \mathrm{T} ; \mathrm{p} . \mathrm{Q70X}$ \\
\hline 3 & - & 14 & $\mathrm{~L}$ & Groin & $\begin{array}{l}\text { Minor lesions on scalp, } \\
\text { neck, soles }\end{array}$ & Aplasia of one finger & $\begin{array}{l}\text { c. } 314 \mathrm{C} \rightarrow \mathrm{T} ; \\
\text { p.A105V }\end{array}$ \\
\hline 4 & + & 15 & $\mathrm{~L}$ & $\begin{array}{l}\text { Diffuse widespread } \\
\text { involvement of leg, trunk, } \\
\text { and hand }\end{array}$ & $\begin{array}{l}\text { Linear lesions on fingers } \\
\text { and toes }\end{array}$ & $\begin{array}{l}\text { Hypoplasia of pelvis } \\
\text { and foot }\end{array}$ & $\begin{array}{l}\text { c. } 314 \mathrm{C} \rightarrow \mathrm{T} \text {; } \\
\text { p.A105V }\end{array}$ \\
\hline 5 & + & - & $\mathrm{L}$ & $\begin{array}{l}\text { Patchy lesions on thigh, } \\
\text { groin, and vulva, linear } \\
\text { lesions on hand and foot }\end{array}$ & $\begin{array}{l}\text { Nail dystrophy one } \\
\text { finger, two toes }\end{array}$ & $\begin{array}{l}\text { Hypoplasia of leg, foot, } \\
\text { and skull }\end{array}$ & $\begin{array}{l}\text { c. } 370 \mathrm{G} \rightarrow \mathrm{A} ; \\
\text { p.G124S }\end{array}$ \\
\hline 6 & - & 16 & $\mathrm{R}$ & $\begin{array}{l}\text { Diffuse involvement of } \\
\text { trunk, upper arm and } \\
\text { thigh, linear lesions on } \\
\text { forearm and lower leg }\end{array}$ & $\begin{array}{l}\text { Minor patchy and linear } \\
\text { lesions on leg and foot }\end{array}$ & $\begin{array}{l}\text { Hypoplasia of arm; } \\
\text { dysplasia of hip and knee }\end{array}$ & $\begin{array}{l}\text { c. } 396 \mathrm{C} \rightarrow \mathrm{G} \text {; } \\
\text { p.C132W }\end{array}$ \\
\hline 7 & - & 17 & L & Trunk and arm & & Hypoplasia of upper arm & $\begin{array}{l}\text { c. } 613 \mathrm{G} \rightarrow \mathrm{A} ; \\
\text { p. } \mathrm{G} 205 \mathrm{~S}\end{array}$ \\
\hline 8 & + & - & $\mathrm{R}$ & $\begin{array}{l}\text { Linear lesions on hand, } \\
\text { foot, scalp, and forehead }\end{array}$ & Linear lesion on one finger & $\begin{array}{l}\text { Hypoplasia of leg and } \\
\text { vertebral column }\end{array}$ & $\begin{array}{l}\text { c. } 894 \mathrm{G} \rightarrow \mathrm{A} \text {; } \\
\text { p.W298X }\end{array}$ \\
\hline 9 & - & 18 & L & $\begin{array}{l}\text { Diffuse and patchy } \\
\text { involvement of neck and } \\
\text { trunk, linear lesions on } \\
\text { extremities }\end{array}$ & Small patches on hand & $\begin{array}{l}\text { Hypoplasia of leg and } \\
\text { vertebral column; syndactyly } \\
\text { of index and middle finger }\end{array}$ & $\begin{array}{l}\text { c. } 906 C \rightarrow A \\
\text { p.Y302X }\end{array}$ \\
\hline 10 & - & 14 & $\mathrm{R}$ & $\begin{array}{l}\text { Patchy and linear } \\
\text { lesions in body folds }\end{array}$ & Minor lesions in body folds & Hypoplasia of arm and leg & $\begin{array}{l}\text { c. } 1018 \mathrm{~T} \rightarrow \mathrm{C} ; \\
\text { p.C340R }\end{array}$ \\
\hline 11 & - & 19 & $\mathrm{R}$ & $\begin{array}{l}\text { Patchy widespread } \\
\text { involvement }\end{array}$ & - & $\begin{array}{l}\text { Elongation of leg; hypoplasia } \\
\text { of vertebrae; verrucous } \\
\text { involvement of vaginal } \\
\text { and gastric mucosae }\end{array}$ & $\begin{array}{l}\text { c. } 1041 \_42 \text { insCATG; } \\
\text { p.G348fs; X358 }\end{array}$ \\
\hline 12 & - & 20 & $\mathrm{R}$ & $\begin{array}{l}\text { Diffuse involvement of } \\
\text { leg, linear lesions on } \\
\text { abdomen and arm }\end{array}$ & - & $\begin{array}{l}\text { Hypoplasia of vertebral } \\
\text { column and hand }\end{array}$ & $\begin{array}{l}\text { c. } 1045 \mathrm{~T} \rightarrow \mathrm{C} ; \\
\text { p.Y349H; } \\
\text { c. } 306 \mathrm{C} \rightarrow \mathrm{T} ; \text { p.F102F }\end{array}$ \\
\hline 13 & - & 21 & $\mathrm{R}$ & $\begin{array}{l}\text { Diffuse involvement of } \\
\text { trunk, forearm, and leg, } \\
\text { extensive linear lesions } \\
\text { on upper arm }\end{array}$ & & $\begin{array}{l}\text { Hypoplasia of arm and leg; } \\
\text { liver lobe hypertrophy; } \\
\text { spleen hypertrophy }\end{array}$ & $\begin{array}{l}\text { c. } 1046 \mathrm{~A} \rightarrow \mathrm{G} ; \\
\text { p.Y349C }\end{array}$ \\
\hline 14 & - & - & L & $\begin{array}{l}\text { Patchy and linear lesions } \\
\text { on trunk and extremities }\end{array}$ & $\begin{array}{l}\text { Patchy and linear lesions } \\
\text { on groin and hand }\end{array}$ & $\begin{array}{l}\text { Hypoplasia of foot and } \\
\text { vertebral column; ipsilateral } \\
\text { deafness; ipsilateral } \\
\text { vocal cord paralysis }\end{array}$ & Complete deletion \\
\hline \multicolumn{8}{|c|}{ NSDHL mutations in CHILD syndrome patients as reported previously } \\
\hline 15 & - & 4 & $\mathrm{R}$, male & $\begin{array}{l}\text { Extensive linear lesions } \\
\text { on trunk and limbs }\end{array}$ & - & Hypoplasia of leg & c. $262 \mathrm{C} \rightarrow \mathrm{T} ; \mathrm{p} . \mathrm{R} 88 \mathrm{X}$ \\
\hline 16 & + & 4 & $\mathrm{R}$ & $\begin{array}{l}\text { Widespread patchy } \\
\text { involvement with } \\
\text { partial resolution }\end{array}$ & $\begin{array}{l}\text { Small linear lesions on } \\
\text { face and arm }\end{array}$ & $\begin{array}{l}\text { Absence of kidney; dilated } \\
\text { cerebral ventricles; hypoplasia } \\
\text { of limbs and vertebral column }\end{array}$ & $\begin{array}{l}\text { c. } 314 \mathrm{C} \rightarrow \mathrm{T} \\
\text { p.A105V }\end{array}$ \\
\hline 17 & - & 4 & $\mathrm{R}$ & $\begin{array}{l}\text { Diffuse widespread } \\
\text { unilateral involvement } \\
\text { with partial resolution }\end{array}$ & $\begin{array}{l}\text { Linear lesions on hand } \\
\text { and thigh }\end{array}$ & $\begin{array}{l}\text { Absence of kidney; hypoplasia } \\
\text { of limbs, mandible, ribs, and } \\
\text { vertebrae }\end{array}$ & $\begin{array}{l}\text { c. } 314 \mathrm{C} \rightarrow \mathrm{T} ; \\
\text { p.A105V }\end{array}$ \\
\hline 18 & - & 8 & $\mathrm{R}$ & $\begin{array}{l}\text { Involvement of the right } \\
\text { axilla, breast, trunk, upper } \\
\text { and lower limb, vulva, } \\
\text { and perineum }\end{array}$ & - & $\begin{array}{l}\text { Hemidysplasia of right } \\
\text { palm; valgity of right } \\
\text { coxofemural joint }\end{array}$ & c. $441 \mathrm{~T} \rightarrow \mathrm{A} ; \mathrm{p} . \mathrm{S} 147 \mathrm{R}$ \\
\hline 19 & - & 6 & $\mathrm{~L}$ & $\begin{array}{l}\text { At birth, erythemathous } \\
\text { rash with minimal scaling } \\
\text { over the chest wall, } \\
\text { linear lesions on leg }\end{array}$ & 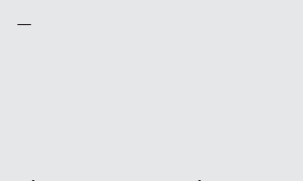 & $\begin{array}{l}\text { Hypoplasia of arm, leg, } \\
\text { and foot; absence of ribs } \\
\text { and hypoplasia of vertebrae; } \\
\text { hypoplastic left lung with } \\
\text { right shift of cardiac } \\
\text { structures; absence of kidney }\end{array}$ & $\begin{array}{l}\text { c. } 451 G \rightarrow T ; \\
\text { p.E151X }\end{array}$ \\
\hline 20 & - & 5 & $\mathrm{R}+\mathrm{L}$ & $\begin{array}{l}\text { Almost symmetrical } \\
\text { involvement of the body } \\
\text { folds; right sided } \\
\text { involvement of neck }\end{array}$ & $\begin{array}{l}\text { Almost symmetrical } \\
\text { involvement of body folds }\end{array}$ & $\begin{array}{l}\text { Hypoplasia of leg and } \\
\text { vertebral column; absence } \\
\text { of facial muscles }\end{array}$ & $\begin{array}{l}\text { c. } 544 G \rightarrow C ; \\
\text { p.A182P }\end{array}$ \\
\hline 21 & - & 4 & $\mathrm{R}$ & $\begin{array}{l}\text { Widespread patchy } \\
\text { unilateral involvement }\end{array}$ & - & $\begin{array}{l}\text { Neurosensory hearing loss; } \\
\text { absence of arm; hypoplasia } \\
\text { of leg }\end{array}$ & $\begin{array}{l}\text { c. } 613 \mathrm{G} \rightarrow \mathrm{A} ; \\
\text { p.G205S }\end{array}$ \\
\hline 22 & - & 4 & $\mathrm{R}$ & $\begin{array}{l}\text { Large patch on the } \\
\text { back, linear lesions } \\
\text { on limbs }\end{array}$ & Linear lesions on hand & $\begin{array}{l}\text { Neurosensory hearing loss; } \\
\text { hypoplasia of vertebral } \\
\text { column and foot }\end{array}$ & $\begin{array}{l}\text { c. } 628 \mathrm{C} \rightarrow \mathrm{T} \\
\text { p.Q210X }\end{array}$ \\
\hline 23 & - & 7 & $\mathrm{~L}$ & $\begin{array}{l}\text { Patchy involvement of } \\
\text { neck and axillae, buttocks, } \\
\text { lower back, and abdomen }\end{array}$ & - & $\begin{array}{l}\text { Shortening of toes } 2,3 \text {, } \\
\text { and } 4\end{array}$ & $\begin{array}{l}\text { c. } 1046 \mathrm{~A} \rightarrow \mathrm{G} ; \\
\text { p.Y349C }\end{array}$ \\
\hline
\end{tabular}


Although case 13 shows the same mutation as observed by Murata and co-workers, ${ }^{7}$ there is no familial relation to our knowledge between the two patients.

\section{Analysis of point mutations}

Genomic DNA was extracted from blood lymphocytes or from cultured fibroblasts following standard procedures. The sequences of intron-exon boundaries and primers, as well as the polymerase chain reaction (PCR) conditions to amplify the eight exons of human NSDHL, have already been described. ${ }^{9}$ Amplified coding exon sequences were analysed both by single strand conformation analysis (SSCA) at two temperatures and by genomic sequencing, as described previously. ${ }^{27} 28$

When a deviant fragment indicative of a mutation was detected in SSCA it was confirmed by a second amplification of the original template, and its presence was searched for in a sample of 100 unrelated individuals to exclude the possibility that it represented a polymorphism. Allele specific sequencing analysis was carried out following amplification of the appropriate gel fragments cut out of the dried SSCA gels. For extraction, gel pieces were incubated in $100 \mu$ l HPLC $\mathrm{H}_{2} \mathrm{O}$ overnight at $37^{\circ} \mathrm{C}$.

Genomic sequence variants not associated with electrophoretic variation in SSCA were confirmed by the amplification refractory mutation system (ARMS) test. ${ }^{29}$

\section{Deletion screening}

To search for minor deletions or duplications affecting NSDHL that would not be detected by either SSCA or genomic sequencing, the copy number of individual exons was determined by hybridisation with amplifiable probes $(\mathrm{MAPH}) .^{30}$ In this approach, locus copy number is measured by amplifying short probes of individual NSDHL exons quantitatively recovered after hybridisation to genomic DNA of a patient. The probes used for quantitative recovery after their hybridisation to immobilised patient DNA were exonic PCR products cloned into the pCR2.1TOPO vector (Invitrogen Inc, San Diego, California, USA). To generate these PCR products, exons 1-7 were amplified with the same primers and conditions as for SSCA, ${ }^{9}$ except for novel reverse primers for exons 4 and 6 (N4br: CAC CCT TAG AAA GGG CCA TC and N6br: TCT CTG AAT GCG AGC ATG GAC). Exon 8 was amplified as two fragments by the use of primer pair

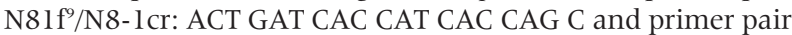
N8-4bf: CCT TCC CCT GTG GAT TGA TG/N8-2br: TGT ACA AGG ACA CTG GAA TG. The annealing temperature for the first of these two pairs was set to $59^{\circ} \mathrm{C}$. All other conditions were as described previously. ${ }^{4}$ One unique probe from chromosomes 5 (St) and 7 (C) each were taken as a control.

\section{Multiple sequence alignment}

The predicted amino acid sequence of human NSDHL (Q15738) was aligned by the use of Clustal $\mathrm{W}^{31}$ with homologous protein sequences identified by a BLAST search in the SWISSPROT database: human (NSDHL_Hs; Q15738) and mouse (Nsdhl Mm; Q9R1J0) (NAD(P) dependent steroid dehydrogenases; Saccharomyces cerevisiae 3 $\beta$-hydroxysteroid dehydrogenase (ERG26_Sc; P53199); Candida albicans C-3 sterol dehydrogenase/C-4 decarboxylase (ERG26 Ca; AAK69617); $3 \beta$-hydroxysteroid dehydrogenases from Macaca mulatta (3BHS_Mam; P27365), Mesocricetus auratus (3BHI Mea; Q60555), and the mouse (3BH1_Mm; P24815)

A putative transmembrane helix was predicted by application of a neural network system. ${ }^{32}$

\section{RESULTS}

\section{Disease causing mutations in NSDHL}

Mutations were searched for in the coding exons (2 to 8) of the NSDHL gene in 14 unrelated female patients with CHILD

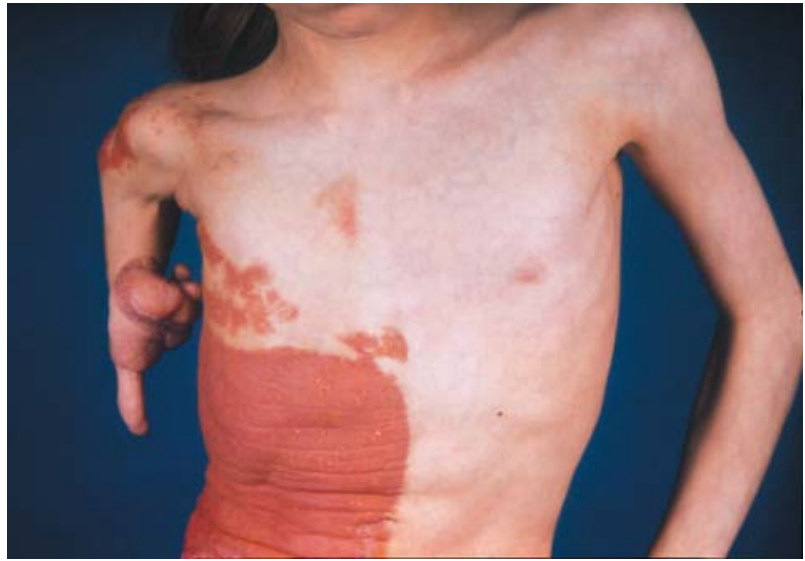

Figure 1 Thirteen year old patient with CHILD syndrome (case 9 table 1): ichthyosiform nevus showing lateralisation with unilateral distribution and midline demarcation; ipsilateral hypoplasia of arm and hand. Reproduced with permission.

syndrome. Brief clinical descriptions of the phenotypes as observed in individual patients and the detected mutations are listed in table 1 . As an example of the phenotype, fig 1 shows the CHILD nevus and limb defects as observed in patient No 9 .

In these 14 patients, in addition to four mutations interrupting the reading frame by the introduction of stop codons, we found eight missense mutations, one mutation affecting a splice site, and one complete deletion of the gene. Two of the patients showed the previously known mutation Al05V. Amino acid Y349 was substituted in two of the patients by $\mathrm{C}$ and $\mathrm{H}$, respectively.

For most of these patients the mutations were detected by SSCA and confirmed by sequencing both strands of the relevant exons. For individuals 1 and 5 (table 1 ), the mutations were identified by genomic sequencing of all exons and subsequently confirmed by an ARMS test (data not shown). None of these mutations was observed in 100 unrelated control individuals.

To search for clustering of mutations in certain domains of the enzyme or genotype- phenotype correlations, the novel cases in table 1 were supplemented by all the other human NSDHL mutations known so far, from six patients previously described by us as well as three mutations identified by other groups. In all, seven stop mutations preventing the translation into full length protein, nine different missense mutations, one mutation affecting a splice site, and one complete deletion of the gene known in humans so far are listed in this table. Four unrelated patients showed the mutation A105V, two had G205S, and two had Y349C. In one case $\mathrm{Y} 349$ was mutated to $\mathrm{H}$.

\section{A deletion of the coding region of NSDHL}

No sequence variation could be detected in one patient (table 1, No 14) with a typical CHILD phenotype. The DNA of this patient was scrutinised by MAPH for microdeletions affecting the NSDHL gene. Locus copy number was measured by amplifying by PCR short probes of NSDHL exons 1-8 quantitatively recovered after hybridisation to genomic DNA of patient No 14. A reduction in the amplified product of all exons to half of the control amount (fig 2, arrows) indicated a deletion of the entire gene. Heterozygosity at three highly polymorphic microsatellite loci-DXS1193, DXS8043, and DXS8106-located on the centromeric side of NSDHL in chromosomal bands Xq28-q27 showed that the deletion did not affect the entire $X$ chromosome (data not shown). 


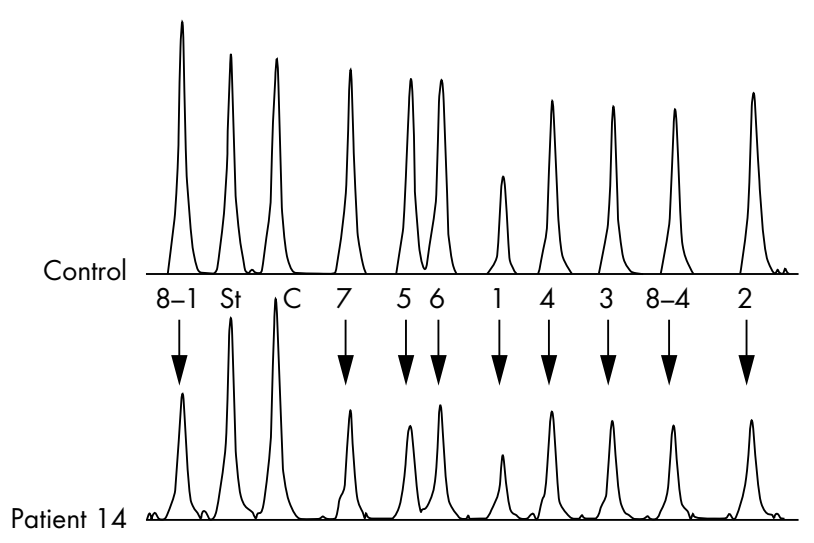

Figure 2 Deletion of NSDHL detected in CHILD patient No 4 (listed in table 1) by the MAPH (measurement by amplifiable probe hybridisation) procedure. Polymerase chain reaction (PCR) products of all exons (labelled 1 to 7 and 8-1, 8-4) were separated on a sequencing gel and the signal intensities were quantified using the Genotyper software (Applied Biosystems). The reduction of the amplified product (arrows) in all exons to half of the amount observed in female control DNA indicates a deletion of the entire gene. St and $C$ are MAPH-PCR products of unique loci on chromosomes 5 and 7 , respectively, used as standards.

\section{Distribution of point mutations along NSDHL}

The deduced amino acid sequences from human NSDHL and other selected $3 \beta$-HSDs were analysed with the CLUSTAL W program (fig 3 ) to demonstrate evolutionary conservation. Amino acids which are identical or show different levels of similarity from man to yeast were aligned.

Above the respective wild type amino acid positions, mutations observed in CHILD patients or in bare patches (Bpa) and striated (Str) mouse strains, which are mutated in the orthologous mouse gene Nsdhl, ${ }^{911}$ are depicted. Putative functional domains of the enzyme-such as the co-factor binding site, the catalytic site, and a transmembrane domain-are marked below their respective amino acid positions. One transmembrane helix was predicted by applying a neural network system. ${ }^{32}$ The species of origin and the SwissProt database accession numbers of the protein sequences, compared in fig 3 with the human enzyme (NSDHL_Hs), are listed in the Methods section. The point mutations in NSDHL are distributed along the coding sequence. Missense mutations preferentially affect highly conserved amino acids, but they are not clustered at known functional domains.

\section{Single nucleotide polymorphism in NSDHL}

In addition to potentially deleterious mutations which were observed in patients only, the search for mutations within the exons revealed one polymorphism occurring in patients, nonaffected family members, and among the non-affected control individuals: c.132G $\rightarrow$ T; p.G44G (data not shown). The frequency of the minor allele among 170 chromosomes from our German control group was $10.6 \%$. This common polymorphism, and a second $($ c.306C $\rightarrow \mathrm{T})$ that was observed only in patient No 12 in addition to a missense mutation, are silent-that is, they do not result in an altered amino acid composition.

\section{DISCUSSION CHILD syndrome appears to be caused by loss of function}

The phenotype of CHILD syndrome appears to be caused by loss of function of NSDHL, as all types of mutations, even the deletion of the whole coding region, result clinically in the same types of defect.

The extent of the naevus on the skin and the developmental defects affecting other sites vary between individuals, most probably because of differences in the $\mathrm{X}$ inactivation pattern. Among the 23 patients in which NSDHL mutations have been identified so far $^{4-8}$ (table 1), eight showed the symptoms preponderantly on the left side of the body, 14 on the right side, and one almost symmetrically on both sides. In several cases other family members were affected as well (table 1). Phenotypic variability appeared not to be associated with the type or site of the mutations. Thus we cannot detect allelic heterogeneity.

In the mouse homolog, however, on phenotypic grounds bare patches (Bpa) and striated (Str) had been described as different mutants, Str being less severely affected than Bpa. $^{33}{ }^{34}$ Genetic mapping had placed them to the same location on the $\mathrm{X}$ chromosome, suggesting that they might be allelic. ${ }^{35}$ The identification of the sites in Nsdhl mutated in each of the known Bpa and Str strains confirmed that they represent allelic mutants. ${ }^{96}$ As in humans, the genotype in the mouse mutants does not allow one to predict the phenotypic outcome (fig 3). Lucas and coworkers ${ }^{36}$ showed that the mouse NSDHL protein can rescue the lethality of erg26 deficient cells of Saccharomyces cerevisiae that lack the yeast orthologue, thus substantiating the role of NSDHL as a C-3 sterol dehydrogenase. Using this yeast complementation assay, they have shown that two Str alleles function as hypomorphs, whereas three Bpa and one Str allele provide no complementation or rescue. The severity of the mouse phenotype, as defined by the timing of the loss of affected male embryos as well as the percentage and phenotype of surviving affected female mice, is not entirely reflected by the order of increased severity in the yeast assay, and neither phenotypic property correlates with the type or site of the underlying mutations.

\section{Missense mutations pinpoint conserved and possibly functionally relevant sites}

Missense mutations associated with loss of function can pinpoint specific domains of particular functional relevance. The position of all NSDHL mutations known so far was correlated with the amino acid alignment of the derived protein sequence of human NSDHL, which has selected homologous protein sequences with C-3 sterol dehydrogenase activity from two yeast and three different mammalian species (fig 3). In addition, the amino acid changes in Nsdhl underlying the seven different bare patches or striated mutant mouse strains are indicated in fig 3.

The multiple sequence alignment shows that the missense mutations in human or murine NSDHL preferentially exchange conserved amino acids. The majority of changes affect amino acids conserved from yeast to man, while three mutations change amino acids conserved at least in human and murine NSDHL.

None of the observed changes directly alters the invariant amino acids that form two previously described conserved motifs, an $\mathrm{N}$ terminal cofactor binding site or the motif T-X$\mathrm{X}$-X-K characteristic for the active site of $3 \beta$-hydroxysteroid dehydrogenases, nor a sequence interval (aa 297-316) predicted to contain a transmembrane helix (fig 3). The high degree of sequence homology in various blocks outside the domains for which a function has been predicted suggests tight restraints on the amino acid composition well beyond the known motifs. The observation of missense mutations in CHILD patients or mouse mutants affecting conserved amino acids supports the view that they affect critical functions of the protein, although in a so far unknown way. 

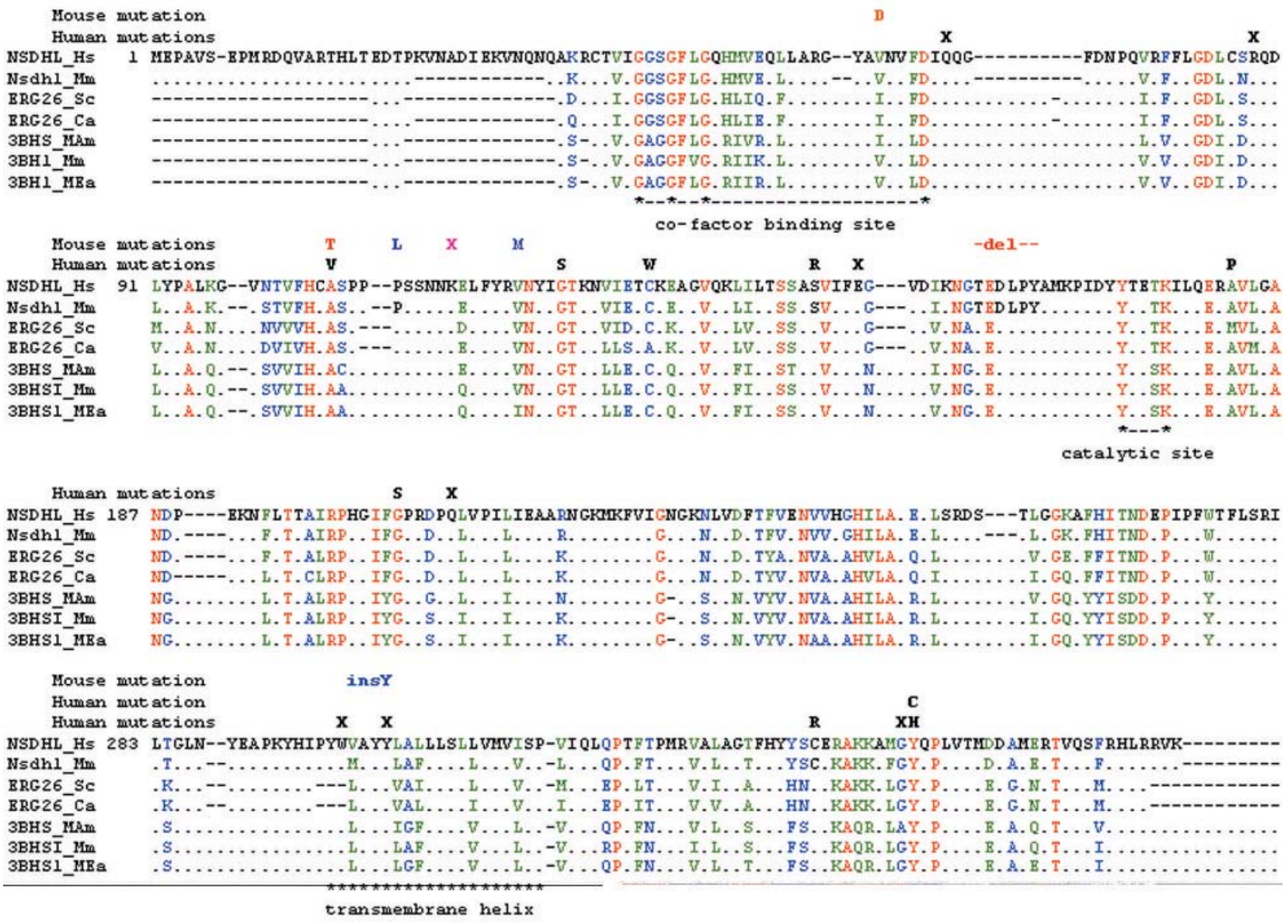

Figure 3 Multiple sequence alignment shows that missense mutations in human or murine NSDHL preferentially exchange conserved amino acids. The

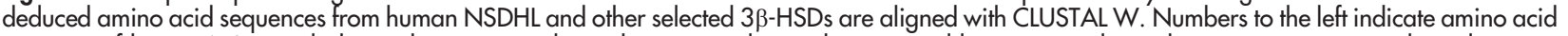
positions of human NSDHL, dashes indicate gaps. Identical amino acids are shown in red letters, strongly similar ones in green; weak similarity is indicated by blue colour, dots represent non-conserved positions. Mutations observed in CHILD patients (black, bold) (table 1) or Bpa (red, bold)/Str (blue, bold) mouse mutants ${ }^{11}$ are depicted above the respective positions. Putative functional domains are marked below the individual sites. The search for transmembrane helices by applying a neural network system ${ }^{32}$ detects one major site. The protein sequences compared to the human enzyme (NSDHL_Hs) are listed in the methods section.

\section{Frequent mutations}

Three amino acids-A105, G205, and Y349-are repeatedly altered among apparently unrelated patients (A105V in four individuals, G205S in two, Y349C in two, and Y349H in one). In one mouse mutant the amino acid A94 of Nsdhl, which takes a homologous position to Al05 in the human enzyme, is mutated to $\mathrm{T}$. The repeated occurrence of mutations at these positions, even across species, could indicate that the gene is particularly prone to mutations at these genomic hotspots or that the function of the protein is specifically dependent on the presence of the proper amino acid at these sites. The amino acids A105 (A94 in mice) and Y349 could be indispensable, as the detrimental effect of their mutation appears to be independent of the amino acid change. However, as long as the role of the conserved domains of the protein and the functional impact of individual missense mutations have not been elucidated experimentally, the explanation for the occurrence of repeated mutation at specific positions remains speculative.

\section{ACKNOWLEDGEMENTS}

We thank all patients and family members for participating in this study. We are grateful to Dr J Armour, Nottingham, for advice on MAPH. Supported by a grant from the Fritz Thyssen Foundation and by the Network for Ichthyoses and Related Keratinization Disorders (NIRK, BMBF BD 224284).

\section{Authors' affiliations}

D Bornholdt, L Leveleki, K-H Grzeschik, Department of Human Genetics, Philipp University, Marburg, Germany

A König, R Happle, M Bittar, R Danarti, Department of Dermatology,

Philipp University

A Vahlquist, Department of Medical Sciences, Uppsala University

Hospital, Uppsala, Sweden

W Tilgen, Department of Dermatology, Saar University, Homburg, Germany

U Reinhold, Clinic for Dermato-oncology, Friedrich-Breuer-Straße, Bonn, Germany

A Poiares Baptista, Department of Dermatology, Faculty of Medicine, Coimbra University, Portugal

É Grosshans, Service de Dermatologie, place de l'Hôpital, Strasbourg, France

P Vabres, Service de Dermatologie, CHU, Poitiers, France

S Niiyama, Department of Dermatology, Kitasato University, Kitasato, Japan

K Sasaoka, Dermatological Clinic, Tomanchi, Nagasaki, Japan T Tanaka, Dermatological Clinic, Nakamurameieki, Aichi, Japan A L Meiss, Department of Orthopaedics, University Hospital HamburgEppendorf, Hamburg, Germany 
P A Treadwell, Departments of Pediatrics and Dermatology, Indiana University School of Medicine, Indianapolis, Indiana, USA

D Lambert, Department of Dermatology, Hôpital du Bocage, Dijon, France

F Camacho, Department of Dermatology, University Hospital Virgen Macarena, Seville, Spain

Competing interests: none declared

Correspondence to: Dr K-H Grzeschik, Department of Human Genetics, Philipp University, Bahnhofstrasse 7, D35037 Marburg, Germany; grzeschi@staff.uni-marburg.de

\section{REFERENCES}

1 Happle R, Koch H, Lenz W. The CHILD syndrome: congenital hemidysplasia with ichthyosiform erythroderma and limb defects. Eur J Pediatr 1980;134:27-33.

2 Happle R, Mittag H, Kuster W. The CHILD nevus: a distinct skin disorder. Dermatology 1995;191:210-16.

3 Fink-Puches R, Soyer HP, Pierer G, Kerl H, Happle R. Systematized inflammatory epidermal nevus with symmetrical involvement: an unusual case of CHILD syndrome? J Am Acad Dermatol 1997;36:823-6.

4 König A, Happle R, Bornholdt D, Engel H, Grzeschik KH. Mutations in the NSDHL gene, encoding a 3beta-hydroxysteroid dehydrogenase, cause CHILD syndrome. Am J Med Genet 2000;90:339-46.

5 König A, Happle R, Fink-Puches R, Soyer HP, Bornholdt D, Engel H, Grzeschik KH. A novel missense mutation of NSDHL in an unusual case of CHILD syndrome showing bilateral, almost symmetric involvement. J Am Acad Dermatol 2002;46:594-6.

6 Hummel M, Cunningham D, Mullett CJ, Kelley RI, Herman GE. Left-sided $\mathrm{CHILD}$ syndrome caused by a nonsense mutation in the NSDHL gene. Am J Med Genet 2003;122A:246-51.

7 Murata K, Shinkai H, Ishikiriyama S, Yamazaki M, Fukuzumi Y, Hatamochi A. A unique point mutation in the NSDHL gene in a Japanese patient with CHILD syndrome. J Dermatol Sci 2003;33:67-9.

8 Kaminska G, Brzezinska-Wcislo L, Jezela-Stanek A, Krajewska-Walasek M, Kelley R. CHILD syndrome - clinical picture, diagnostic procedures and treatment. J Eur Acad Dermatol Venereol 2003;17:276.

9 Liu XY, Dangel AW, Kelley RI, Zhao W, Denny P, Botcherby M, Cattanach B, Peters J, Hunsicker PR, Mallon AM, Strivens MA, Bate R, Miller W, Rhodes M, Brown SD, Herman GE. The gene mutated in bare patches and striated mice encodes a novel 3beta-hydroxysteroid dehydrogenase. Nat Genet 1999;22:182-7

10 Ohashi M, Mizushima N, Kabeya Y, Yoshimori T. Localization of mammalian NAD(P)H steroid dehydrogenase-like protein on lipid droplets. J Biol Chem 2003;278:36819-29.

11 Caldas H, Herman GE. NSDHL, an enzyme involved in cholesterol biosynthesis, traffics through the Golgi and accumulates on ER membranes and on the surface of lipid droplets. Hum Mol Genet 2003;12:2981-91.

12 Lambert D, Dalac S, Alison M, Mabille JP. Epidermal nevus associated with ganglioneuroblastoma. In: Wilkinson DS, Mascaro JM, Orfanos CE, eds. Clinical dermatology: the CMD case collection. World Congress of Dermatology Berlin, May 24-29, 1987. Stuttgart: Schattauer, 1987:48-9.

13 Peter C, Meinecke P. CHILD-Syndrom: Fallbericht einer seltenen Genodermatose. Hautarzt 1993;44:590-3.

14 Vabres P, Amati-Bonneau P, Hamel-Teillac D, De Prost $Y$, Larregue M, Bonneau $D$. Inactivation non-aleatoire du chromosome $X$ dans le syndrome CHILD. Ann Dermatol Venereol 2000;127:4S92-3.

15 Poiares Baptista A, Cortesao JM. Naevus epidermique inflammatoire variable (N.E.V.I.L. atypique? Entite nouvelle?). Ann Dermatol Venereol (Paris) 1979; 106:443-50.

16 Schlenzka K, Gehre M, Neumann HJ, Sochor H. CHILD-Syndrom kasuistischer Beitrag zur Kenntnis dieser seltenen Genodermatose. Dermatol Monatsschr 1989;175:100-6.
17 Tanaka T, Ito M, Yasuma M, Sakuma T, Suzuki T, Kuroyanagi M. CHILD syndrome: congenital hemidysplasia with ichthyosiform erythroderma and limb defects. Pract Dermatol 1982;4:143-6. [In Japanese.]

18 Garcia-Bravo B, Rodriguez-Pichardo A, Konig A, Grzeschik KH, Happle R, Camacho F. Un nuevo caso de sindrome CHILD diagnosticado previamente como nevo epidermico verrugoso inflamatorio lineal (NEVIL). Med Cutan Iber Lat Am 2002;30:120-5.

19 Vahlquist A, Ganemo A, Pigg M, Virtanen M, Westermark P. The clinical spectrum of congenital ichthyosis in Sweden: a review of 127 cases. Acta Derm Venereol Suppl (Stockh) 2003;213:34-47.

20 Laplanche G, Grosshans E, Gabriel-Robez O, Happle R, Enjolras O. Hyperplasie epidermique et hemidysplasie corporelle hypoplastique congenitales homolaterales: Demembrement du syndrome de Solomon. Ann Dermatol Venereol (Paris) 1980;107:729-39.

21 Sasaoka T, Nishimoto S, Norimasa A, Funamoto T, Nokita M, Ashizuka T. Congenital unilateral ichthyosiform erythroderma. Rinsho Derma 1973; 15:639-49.

22 Happle R. X-linked dominant chondrodysplasia punctata: review of the literature and report of a case. Hum Genet 1979;53:65-73.

23 Braverman N, Lin P, Moebius FF, Obie C, Moser A, Glossmann H, Wilcox WR, Rimoin DL, Smith M, Kratz L, Kelley RI, Valle D. Mutations in the gene encoding 3 beta-hydroxysteroid-delta 8, delta 7-isomerase cause Xlinked dominant Conradi-Hunermann syndrome. Nat Genet 1999;22:291-4.

24 Derry JM, Gormally E, Means GD, Zhao W, Meindl A, Kelley RI, Boyd Y, Herman GE. Mutations in a delta 8-delta 7 sterol isomerase in the tattered mouse and X-linked dominant chondrodysplasia punctata. Nat Genet 1999;22:286-90.

25 Grange DK, Kratz LE, Braverman NE, Kelley RI. CHILD syndrome caused by deficiency of 3beta-hydroxysteroid-delta8, delta7-isomerase. Am J Med Genet 2000;90:328-35.

26 Happle R, Karlic D, Steiilen PM. CHILD-Syndrom bei Mutter und Tochter. Hautarzt 1990;41:105-8.

27 Kalff-Suske $M$, Wild A, Topp J, Wessling $M$, Jacobsen EM, Bornholdt $D$ Engel $H$, Heuer $H$, Aalfs $C M$, Ausems MG, Barone R, Herzog A, Heutink $P$ Homfray T, Gillessen-Kaesbach G, R K, Kunze J, Meinecke P, D M, Rizzo R, Strenge S, Superti-Furga A, Grzeschik KH. Point mutations throughout the GLI3 gene cause Greig cephalopolysyndactyly syndrome. Hum Mol Genet 1999;8:1769-77.

28 Wild A, Kalff-Suske M, Vortkamp A, Bornholdt D, Konig R, Grzeschik KH. Point mutations in human GLI3 cause Greig syndrome. Hum Mol Genet 1997;6: 1979-84

29 Newton CR, Graham A, Heptinstall LE, Powell SJ, Summers C, Kalsheker N, Smith JC, Markham AF. Analysis of any point mutation in DNA. The amplification refractory mutation system (ARMS). Nucleic Acids Res 1989;17:2503-16.

30 Armour JA, Sismani C, Patsalis PC, Cross G. Measurement of locus copy number by hybridisation with amplifiable probes. Nucleic Acids Res 2000;28:605-9.

31 Thompson JD, Higgins DG, Gibson TJ. CLUSTAL W: improving the sensitivity of progressive multiple sequence alignment through sequence weighting, position-specific gap penalties and weight matrix choice. Nucleic Acids Res position-specific gap
1994;22:4673-80.

32 Rost B, Casadio R, Fariselli P, Sander C. Transmembrane helices predicted at 95\% accuracy. Protein Sci 1995:4:521-33.

33 Phillips RJS, Hawker SH, Moseley HJ. Bare-patches, a new sex-linked gene in the mouse, associated with a high production of XO females. I. A preliminary report of breeding experiments. Genet Res 1973;22:91-9.

34 Phillips RJS. Striated, a new sex-linked gene in the house mouse. Genet Res 1963;4:93-103.

35 Angel TA, Faust CJ, Gonzales JC, Kenwrick S, Lewis RA, Herman GE. Genetic mapping of the X-linked dominant mutations striated (Str) and bare patches (Bpa) to a 600-kb region of the mouse $X$ chromosome: implications for mapping human disorders in Xq28. Mamm Genome 1993:4:171-6.

36 Lucas ME, Ma Q, Cunningham D, Peters J, Cattanach B, Bard M, Elmore BK, Herman GE. Identification of two novel mutations in the murine Nsdhl sterol dehydrogenase gene and development of a functional complementation assay in yeast. Mol Genet Metab 2003;80:227-33. 